\title{
Kekontraktifan Pemetaan pada Ruang Metrik Kerucut
}

\author{
Badrulfalah dan Iin Irianingsih \\ Jurusan Matematika, Fakultas MIPA, Universitas \\ Jl. Raya Bandung Sumedang KM 21 Jatinangor Sumedang 45363 \\ e-mail: badrulfalah2010@yahoo.co.id
}

\begin{abstract}
ABSTRAK
Makalah ini membahas tentang pemetaan kontraktif pada ruang metrik kerucut dengan bentuk syarat kontraktif tertentu, khususnya mengenai eksistensi titik tetapnya. Dengan menggunakan sifat Cauchy dari barisan iteratif, dapat dibuktikan bahwa pemetaan kontraktif pada ruang metrik kerucut dengan syarat terkait memiliki titik tetap tunggal.
\end{abstract}

Kata Kunci: ruang metrik kerucut, pemetaan kontraktif, barisan Cauchy, titik tetap.

\section{ABSTRACT}

This paper discusses a contractive mapping with form certainty contractive condition on cone metric space, especially about an existence of its fixed point. By using an iterative sequence and definition of Cauchy sequence, we can prove that the mapping has a unique fixed point on cone metric space.

Key words: cone metric space, contractive mapping, Cauchy sequence, fixed point.

\section{Pendahuluan}

Huang dan Zhang dalam [2] telah mendefinisikan ruang metrik kerucut yang merupakan perluasan dari ruang metrik [1]. Rezapour, Sh. \& Hamlbarani, R. [3] membahas tentang titik tetap pemetaan kontraktif pada ruang metrik kerucut dengan berbagai syarat kekontraktifan. Berdasarkan hasil tersebut pada makalah ini akan dibahas titik tetap pemetaan kontraktif pada ruang metrik kerucut dengan syarat kekontraktifan yang sedikit berbeda dari salah satu syarat kekontraktifan yang terdapat pada Rezapour, Sh.\& Hamlbarani R. [3]. Pertama diberikan definisi kekontraktifan. Berikutnya ditentukan syarat nilai konstanta kontraktif dari pemetaan tersebut agar titik pemetaan memiliki titik tetap tunggal. Terakhir dengan menggunakan sifat Cauchy dari barisan iteratif, dapat dibuktikan bahwa pemetaan kontraktif pada ruang metrik kerucut yang memenuhi syarat tersebut memiliki titik tetap tunggal. Untuk itu sebelumnya berikut ini diberikan beberapa definisi terkait.

Definisi 1: (Rezapour, Sh. dan Hamlbarani, R. [3]) Misal E ruang Banach Real dan $P \subseteq E$. $P$ dinamakan kerucut jika:

(i) $P \neq \emptyset$, tutup dan $P \neq\{0\}$, 
(ii) $a x+b y \in P$ untuk setiap $x, y \in P$ dan $a, b$ bilangan real non-negatif

(iii) $P \cap(-P)=\{0\}$.

Pada definisi berikut diasumsikan bahwa $\mathrm{E}$ ruang Banach, $P$ kerucut di $\mathrm{E}$ dengan int $P \neq \emptyset$ dan $\leq$ adalah pengurutan parsial terhadap $P$.

Definisi 2: (Huang dan Zhang, X. [2]) Misal $X \neq \emptyset$ dan misalkan $d: X \times X \rightarrow E$ memenuhi:

(i) $0 \leq d(x, y)$ untuk setiap $x, y \in X$ dan $d(x, y)=0$ jika dan hanya jika $x=y$.

(ii) $d(x, y)=d(y, x)$ untuk setiap $x, y \in X$.

(iii) $d(x, y) \leq d(x, z)+d(z, y)$ untuk setiap $x, y, z \in X$.

Maka $d$ disebut metrik kerucut pada $X$, dan $(X, d)$ disebut ruang metrik kerucut.

Definisi 3: (Huang dan Zhang, X. [2]) Misal $(X, d)$ ruang metrik kerucut, $x \in X$ dan $\left(x_{n}\right)$ barisan di $X$. Maka $\left(x_{n}\right)$ konvergen ke $x$ apabila untuk setiap $c \in E$ dengan $0 \ll c$ terdapat bilangan asli $N$ sedemikian sehingga $d\left(x_{n}, x\right) \ll c$ untuk setiap $n \geq N$.

Definisi 4: (Huang dan Zhang, X. [2]) Misal (X,d) ruang metrik kerucut, $x \in X$ dan $\left(x_{n}\right)$ barisan di $X .\left(x_{n}\right)$ barisan Cauchy bila untuk setiap $c \in E$ dengan $0 \ll c$ terdapat bilangan asli $N$ sedemikian sehingga

$d\left(x_{n}, x_{m}\right) \ll c$ untuk setiap $n, m \geq N$.

Definisi 5: (Huang dan Zhang, X. [2]) Misal $(X, d)$ ruang metrik kerucut, $x \in X$ dan $\left(x_{n}\right)$ barisan di $X .(X, d)$ disebut ruang metrik kerucut lengkap jika setiap barisan Cauchy di $X$ konvergen ke titik di $X$.

Definisi 6: (Goldberg dan Richard, R. [1]) Misal T:X $\rightarrow X . x \in X$ dinamakan titik tetap $T$ jika $T x=x$.

\section{Tinjauan Pustaka}

Pandang E ruang Banach Real yang terurut secara parsial oleh kerucut $P \subseteq E$ Misal $X \neq \emptyset,(X, d)$ ruang metrik kerucut, dan T adalah pemetaan dari $X$ ke $X$. Huang, L.G \& Zhang, X [2] telah membuktikan beberapa teorema pemetaan kontraktif dengan berbagai syarat kekontraktifan. Sedangkan pada makalah ini akan dibahas pemetaan kontraktif dengan syarat yang berbeda dari yang telah diberikan Rezapour Sh. dan Hamlbarani R. [3] dengan mengubah sedikit bentuk syarat dari salah satu kekontraktifan yang ada pada Rezapour, Sh. dan Hamlbarani, R. [3]. Berikut ini diberikan salah satu dari empat definisi kekontraktifan dengan bentuk syarat berbeda seperti yang terdapat pada Rezapour, Sh.dan Hamlbarani, R. [3]. 
Definisi 7: (Rezapour, Sh. dan Hamlbarani R. [3]) Misal $T: X \rightarrow X . T$ dikatakan memenuhi kondisi kontraktif jika $d(T x, T y) \leq k d(x, y)+l d(y, T x)$, untuk setiap $x, y \in X$, dimana $k, l \in[0,1)$.

Selanjutnya pada definisi 8 berikut diberikan definisi kontraktif yang sedikit berbeda dari Definisi Kontraktif pada Definisi 7 dengan mengubah suku kedua pada ruas kanan.

Definisi 8: Misal $T: X \rightarrow X . T$ dikatakan memenuhi syarat kontraktif jika $d(T x, T y) \leq k d(x, y)+l d(x, T y)$, untuk setiap $x, y \in X$, dimana $k, l \in[0,1)$.

Contoh 9: Misalkan $E=\mathbb{R}, P=\{x \in \mathbb{R} \mid x \geq 0\}$ dan $X=[0,1]$ maka $P$ adalah kerucut.

Selanjutnya $d: X \times X \rightarrow E$ didefinisikan oleh $d(x, y)=|x-y|$. Maka $(X, d)$ ruang metrik kerucut lengkap.

i. Jika $T: X \rightarrow X$ didefinisikan oleh $T x=x^{2}$ maka $T$ tidak memenuhi definisi kekontraktifan seperti pada Definisi 8 karena $k=1 \notin[0,1), l=\frac{1}{2}$. Dalam hal ini $k+l=\frac{3}{2}$. Dan $T$ memiliki dua titik tetap yaitu $x=0$ dan $x=1$. Dengan kata lain $T$ tidak memiliki titik tetap tunggal.

ii. Jika $T: X \rightarrow X$ didefinisikan oleh $T x=\frac{x^{2}}{3}$ maka $T$ memenuhi definisi kekontraktifan seperti pada Definisi 8 dengan $k=\frac{1}{3} \quad$ dan $\quad l=\frac{1}{2}$. Dalam hal ini $k+l=\frac{5}{6}<1$. Dan $T$ memiliki satu titik tetap yaitu $x=0$. Dengan kata lain $T$ memiliki titik tetap tunggal.

Berdasarkan contoh tersebut di atas, diperoleh asumsi bahwa $k+l<1$ juga merupakan syarat cukup untuk pemetaan kontraktif berbentuk seperti pada Definisi 8 memiliki titik tetap tunggal. Pembuktiannya akan diberikan oleh teorema 1 pada hasil berikut.

\section{Hasil}

Eksistensi dan ketunggalan titik tetap pemetaan pada ruang metrik kerucut lengkap dengan syarat berbentuk seperti pada definisi 8 dinyatakan pada teorema 1 berikut.

Teorema 1: Misal $(X, d)$ ruang metrik kerucut lengkap dan $T: X \rightarrow X$ memenuhi syarat kontraktif seperti pada definisi 8 yaitu

$d(T x, T y) \leq k d(x, y)+l d(x, T y)$, untuk setiap $x, y \in X$, dimana $k, l \in[0,1)$ adalah konstanta. Maka T memiliki titik tetap di X. Jika $k+l<1$ maka titik tetap dari T adalah tunggal.

Bukti:

Untuk setiap $x_{0} \in X$ dan $n \geq 1$, definisikan $x_{1}=T x_{0}$ dan $x_{n+1}=T x_{n}=T x_{0}{ }^{n+1}$. 
Akan diperlihatkan $\left(x_{n}\right)$ barisan Cauchy.

$$
\begin{aligned}
& d\left(x_{n+1}, x_{n}\right)=d\left(T x_{n}, T x_{n-1}\right) \leq k d\left(x_{n}, x_{n-1}\right)+l d\left(x_{n}, T x_{n-1}\right)=k d\left(x_{n}, x_{n-1}\right) \leq \\
& k^{n} d\left(x_{1}, x_{0}\right) \\
& \text { Dengan demikian untuk } n>m \text { diperoleh } \\
& d\left(x_{n}, x_{m}\right) \leq d\left(x_{n}, x_{n-1}\right)+d\left(x_{n-1}, x_{n-2}\right)+\cdots+d\left(x_{m+1}, x_{m}\right) \\
& \leq\left(k^{n-1}+k^{n-2}+\cdots k^{m}\right) d\left(x_{1}, x_{0}\right) \leq \frac{k^{m}}{1-k} d\left(x_{1}, x_{0}\right) \text {. }
\end{aligned}
$$

Diberikan $c \gg 0(c \in E)$.

Pilih $N_{1} \in \mathbb{N}$ sedemikian sehingga $\frac{k^{m}}{1-k} d\left(x_{1}, x_{0}\right) \ll c$, untuk setiap $m \geq N_{1}$. Jadi $\left.d\left(x_{n}, x_{m}\right)\right) \ll c$, untuk setiap $n>m$.

Oleh karena itu , menurut definisi 4 maka $\left(x_{n}\right)$ adalah barisan Cauchy di $(X, d)$.

Karena $(X, d)$ ruang metrik kerucut lengkap menurut definisi 5 maka $\left(x_{n}\right)$ konvergen ke $x^{*} \in X$.

Selanjutnya akan diperlihatkan $x^{*} \operatorname{titik} \operatorname{tetap} T$.

Karena $x_{n}$ konvergen ke $x^{*}$ maka dapat dipilih $N_{2} \in \mathbb{N}$ sedemikian sehingga $d\left(x_{n}, x^{*}\right) \ll \frac{c}{3}$, untuk setiap $n \geq N_{2}$.

Oleh karena itu untuk $n \geq N_{2}$, diperoleh

$$
\begin{aligned}
d\left(T x^{*}, x^{*}\right) \leq d\left(T x^{*},\right. & \left.x_{n}\right)+d\left(x_{n}, x^{*}\right)=d\left(T x^{*}, T x_{n-1}\right)+d\left(x_{n}, x^{*}\right) \\
& \leq k d\left(x^{*}, x_{n-1}\right)+l d\left(T x_{n-1}, x^{*}\right)+d\left(x_{n}, x^{*}\right) \\
& \leq d\left(x^{*}, x_{n-1}\right)+d\left(x_{n}, x^{*}\right)+d\left(x_{n}, x^{*}\right) \ll \frac{c}{3}+\frac{c}{3}+\frac{c}{3}=c .
\end{aligned}
$$

Dengan demikian $d\left(T x^{*}, x^{*}\right) \ll \frac{c}{m}$, untuk setiap $m \geq 1$.

Karena itu $\frac{c}{m}-d\left(T x^{*}, x^{*}\right) \in P$, untuk setiap $m \geq 1$. Karena $\frac{c}{m} \rightarrow 0$ dan $P$ tutup maka $-d\left(T x^{*}, x^{*}\right) \in P$. Tetapi $d\left(T x^{*}, x^{*}\right) \in P$.

Oleh karena itu menurut definisi 4 maka $d\left(T x^{*}, x^{*}\right)=0$. Jadi $T x^{*}=x^{*}$. Dengan kata lain, menurut definisi 6 maka $x^{*}$ adalah titik tetap $T$.

Terakhir diperlihatkan $x^{*}$ titik tetap tunggal $T$.

Misal $y^{*}$ titik tetap lain dari $T$ dan $k+l<1$, maka

$d\left(x^{*}, y^{*}\right)=d\left(T x^{*}, T y^{*}\right) \leq k d\left(x^{*}, y^{*}\right)+l d\left(x^{*}, T y^{*}\right)=(k+l) d\left(x^{*}, y^{*}\right)$.

Karena itu $d\left(x^{*}, y^{*}\right)=0$. Jadi $x^{*}=y^{*}$.

Oleh karena itu titik tetap $T$ tunggal apabila $k+l<1$. Terbukti

\section{Simpulan}

Berdasarkan pembahasan diperoleh kesimpulan bahwa pemetaan kontraktif pada ruang metrik kerucut lengkap dengan syarat kekontraktifan seperti dinyatakan pada definisi 8 memiliki titik tetap tunggal asalkan jumlah dari kedua konstanta kontraksinya lebih kecil dari satu. 


\section{Daftar Pustaka}

1. Goldberg, Richard R., 1976, Methods of Real Analysis, Second Edition, John Wiley \& Sons, Inc. New York.

2. Huang, L. G., Zhang, X., 2007. Cone metric spaces and fixed point theorems of contractive mapping, Journal of Mathematical Analysis and Application, Vol.332, no.2, pp 1468-1476.

3. Rezapour, S, Hamlbarani, R., 2008., Some notes on the paper " Cone metric spaces and fixed point theorems of contractive mappings", J. Math. Anal. Appl. 345, pp 719-724. 